\title{
Overview of Insomnia
}

\author{
윤 인 영
}

분당서울대병원 신경정신과

\section{Introduction}

1) 불면증이란 환자자신이 느끼기에 잠이 불충분하거나 비 정상적인 상태로 잠이 들기 힘들거나, 자다가 자주 깨거나, 한번 깨면 다시 잠들기 힘들거나, 수면시간이 짧다고 느끼거 나, 잠을 자도 개운하지 않다고 느끼는 등 여러 가지 형태가 복합적으로 혹은 단독으로 나타난다.

2) 불면증의 기간이 한 달 미만이면 일시적 불면증이라 하 고 6개월 이상(혹은 1 개월 이상. ICSD vs DSM IV)이면 만성적 불면증이라고 하는데 일시적 불면증은 전 인구의 $1 / 3$ 에서, 만성적 불면증은 전 인구의 $10 \%$ 내외에서 경험하 는 것으로 알려져 있다.

3) 불면증을 대했을 때에 기본적으로 취할 태도는 불면증 이 진단명이 아니라 발열이나 두통 같은 하나의 증상이라는 점이다. 우리가 두통환자나 열이 나는 환자를 대했을 때에 무조건 두통약이나 해열제를 주기 전에 그 원인에 대해 생각 하듯이 불면증환자를 처음 대했을 때에 어떤 원인이 있는 것 이 아닌가 생각해야 하며 특히 만성적 불면증환자나 노인환 자의 경우 그렇다.

4) 불면증을 2 차적으로 초래하는 대표적인 질환은 수면무호 흡증, 우울증, 주기적 사지운동증(periodic limb movements during sleep, PLMS), 하지불안증후군(restless legs syndrome, RLS), 약물남용이나 금단, 통증(alpha-delta sleep pattern/fibrositis, rheumatoid arthritis, post-

\footnotetext{
* Address for correspondence In-Young Yoon, M.D., Ph.D.

Department of Neurology, Seoul National University College of Medicine, Seoul National University Bundang Hospital

300 Gumi-dong, Bundang-gu, Seongnam-si, Gyeonggi-do, 463-707, Korea Tel: +82-31-787-7463 Fax: +82-31-719-6828

E-mail : jisookim@snu.ac.kr
}

traumatic and other pain disorders) 등이 있다.

5) 만성적 불면증환자나 노인환자를 대할 경우 혹은 불면 증의 원인이 의심될 때는(특히 수면무호흡증, 주기적 사지운 동증, 하지불안증후군 등) 야간수면다원검사시행을 고려해 볼 수 있다.

6) 앞에서 언급한 이유 없이 혹은 심리적 요인으로 불면증을 호소할 때 이를 DSM-IV에서는 일차적 불면증(primary insomnia)라고 하며 ICSD (International Classification of Sleep Disorders)에서는 이를 3가지로 나누어 기술한다. 즉, - psychophysiologic insomnia

- idiopathic insomnia

: 수면-각성상태를 조절하는 신경구조의 이상으로 어린 시절부터 지속적으로 적절한 수면을 취하지 못하는 상태

- sleep state misperception

: 객관적인 소견 상(검사 혹은 병력) 이상이 없는데도 불면증을 호소하는 상태

\section{Pharmacotherapy}

1) 불면증의 원인이 발견되었을 때에는(예; 우울증, 하지 불안증후군, 주기적사지운동증 등) 이에 적절한 약물치료를 한다. 수면클리닉에 불면증을 호소하며 찾아오는 환자 중 $50 \%$ 내외는 우울증으로 생각된다.

2) 정신생리적(일차성) 불면증의 약물치료

(1) Benzodiazepine - 2 wks 미만 사용하도록, tolerance and dependency의 문제

Nonbenzodiazepine - Benzodiazepine 만큼 보고가 
많지만 않으나 tolerance and dependency의 문제가 있음. Zopiclone $\left(\operatorname{Imovan}^{\mathbb{R}}\right)$, Zolpidem $\left(\right.$ Stionox $\left.{ }^{\mathbb{R}}\right)$, Zaleplon (Sonata ${ }^{\mathbb{R}}$ )

(2) Antidepressant - amitriptyline/trazodone/mirtazapine $\left(\right.$ Remeron $\left.{ }^{\mathbb{R}}\right)$, 내성과 의존의 문제는 적다. 효과를 입 증한 연구는 많지 않다

(3) Antihistamine ( $\mathrm{H}_{1}$ blocker) - sleep보다는 vigilance 와 연관

Caffeine, methylxanthines - adenosine antagonist

\section{Cognitive-Behavioral Therapy}

인지행동치료는 불면증의 상당수를 차지하는 정신생리적 불면증에 가장 효과적이나 어떤 원인으로 인한 불면증에서도 도움을 줄 수 있다.

\section{1. 정상 수면에 대한 이해}

노화에 따라 자주 깨고, 아침에 일찍 잠이 깨는 현상이 정 상적인 것을 설명하고 정상 수면의 기준치를 너무 높게 잡지 않도록 한다. 정상적으로 사람이 얼마나 자야하는가 하는 기 준이 없음을 설명하고 낮시간에 활동하는데 지장이 없는 정 도면 비록 짧은 시간을 자더라도 문제가 아니라고 설명한다.

\section{2. 올바른 수면 위생}

a. 일정한 기상 시간 - 일주기 리듬의 설정(circadian rhythm setting)에 있어서 기상 시간이 취침 시간보다 중요

b. 적절한 운동 - 저녁 시간의 운동은 오히려 교감 신경을 자극한다.

c. 자기 전에 간단한 군것질은 괜창다 - 공복은 수면을 방 해할 수 있다.

d. 낮잠은 가능한 피하는 것이 좋다 - 참기 힘들면 오후 2-3 시경에 잠깐 자도록 하라. 오후 늦게 자는 것은 절대 피해 야 한다(homeostic factor vs circadian factor).

\section{3. 수면제한치료(sleep restriction therapy)}

불면증에 걸린 환자들은 자신의 부족한 잠을 보충하기 위 해 시간이 나면 누으려고 하고 저녁에도 일찌감치 잠자리에 들어간다. 이렇게 취침 시간을 길게 하면 수면의 농도나 효
율이 떨어지고 수면이 회복기능을 상실한다. 불면증 환자의 경우 오히려 수면 시간을 제한해야 한다. 평소에 11시부터 7 시까지 잤던 사람이면 1 시부터 7 시까지 자도록 하고 잘 자 게 되면 시간을 조금씩 늘려 나간다. 취침 시간 이외에는 침 실에 들어가거나 누워있거나 하면 안된다.

\section{4. 자극 조절 치료(stimulus control therapy)}

a. 침실에서 수면에 방해되는 물건은 모두 치운다. 특히 시 계는 불면증 환자의 “천적"이므로 방에서 치우든지 아니 면 시계침을 보지 못하도록 돌려놓아야 한다. 불면증 환 자는 잠을 못 이루거나 자다가 깨게 되면 시계를 보면서 자기가 지금까지 자려고 싸웠던 시간과 앞으로 자야 할 시간을 계산하며 초조하고 불안해한다. 이렇게 되면 교 감 신경이 더욱 자극되면서 잠은 더욱 안오게 된다.

b. 침실에서는 잠자는 행동 이외에 어떠한 행동도 금해야 한다. 혹자는 침실에서 TV나 책을 보기도 하고 직장에 서 못 다한 일을 하기도 하는데 이러한 행동은 금해야 한다. 침실은 잠을 자는 곳이라는 조건화를 이루어야 한다. 잠자리에 누워서 하루 일을 걱정하는 것도 옳지 않은데 생각해야 일이 있을 경우 따로 시간을 할당하여 야 한다(worry time).

cf) on-off switch

c. 앞에서 언급한 대로 침실은 자는 곳이라는 조건화를 형 성해야 한다. 취침 시간이 되어 잠자리에 들었다가 잠이 오지 않으면 거실로 나와서 조용히 걷든가 이완 요법을 한다. 그래서 다시 잠이 오게 되면 침실로 들어간다. 이 번에도 잠이 오지 않으면 같은 과정을 반복한다. 이렇게 함으로써 침실은 쉽게 잠드는 곳이라는 새로운 연결고 리(reconditioning)를 형성하는 것이다.

\section{5. 이완 치료(relaxation therapy)}

a. 불면증 환자의 경우 다음과 같은 2 가지 문제를 가지게 된다. 첫째, 스트레스에 민감하게 반응하여 자주 초조 와 불안을 보이고 긴장과 교감 신경이 항진된 소견을 보인다. 둘째, 자신의 불면증상에 지나치게 신경 쓰고 사로잡혀서 매일 잠자리에 누우면 '과연 오늘은 내가 잘 잘 수 있을까'하는 불안에 사로잡히면서 자려고 노력하 게 된다. 자려고 노력할수록 더욱 교감신경이 항진되면 서 잠은 오지 않게 되고 그러면서 불안은 더욱 심해지 고 더욱 자려고 노력하게 된다. 계속적인 악순환의 고 
리를 밟게 된다.

b. 이완 요법은 우선 부교감 신경의 항진을 통해 교감 신경 을 억제함으로써 불면증 환자의 첫 번째 문제를 해결하 게 된다. 한편 이완 치료 시 환자가 자신이 잠을 자야한 다는 생각에 사로잡혀 불안해하는 대신에 이완요법에 집중하게 함으로써 불안으로부터 주위를 분산시켜 악순 환의 고리를 끊을 수 있게 되는 것이다.

c. 많이 사용되는 이완 치료로는 복식 호흡법(diaphragmatic or abdominal breathing), 점진적 근육 이완법, 상상법(imagery), 최면을 이용한 근육 이완법 혹은 상상 법 등이 있다.

\section{6. 광치료(light therapy)}

a. 일정 강도이상의 빛을 저녁 혹은 이른 밤에 비추면 일주 기 리듬의 위상 지연(phase delay)이 일어나고 새벽에 비추면 일주기 리듬의 위상 전진(phase advance)이 일어난다는 사실을 이용하여 불면증이 일주기 리듬 장 애에 의한 것일 경우 광치료를 사용하게 된다.

b. 노년기에 보이는 불면증은 입면장애보다는 수면유지곤 란과 연관이 있으며 일찍 잠들어서 일찍 깨어나는 특징 을 보인다. 심부체온(core body temperature) 혹은 멜라토닌으로 일주기리듬을 측정하였을 때 위상이 전진 된 소견을 보이며 이로 인해 새벽에 일찍 깨는 것으로 생각된다. 따라서 2,500 룩스 내외의 빛을 저녁시간 (10시전후)에 1-2시간 비추게 되면 위상 지연이 일어 나 일주기 리듬이 교정되면서 수면 개선 효과를 기대할 수 있다. 나이와 관계없이 밤에 잠들기는 쉬우나 새벽
에 일찍 깨는 불면증의 경우 위상 전진이 의심되므로 저녁 시간에 광치료를 생각해 볼 수 있다.

c. 입면 곤란을 호소하거나 자고 난 후 바로 깨는 증상을 호소하는 불면증의 경우 위상 지연을 의심할 수 있으므 로 아침에 광치료를 시도하여 위상 전진을 시키면 불면 증이 호전되는 것을 기대할 수 있다.

\section{Conclusions}

1) 불면증은 수면제로 치료한다는 기계적 태도를 버리고 불면증 환자를 대하면 어떤 원인이 있는 것이 아닌가를 반드 시 찾아보아야 한다. 임상에서 흔히 접하게 되는 불면증의 원인은 우울증이며 이외 수면무호흡증, 하지불안증후군, 주 기적사지운동증 등이 있다.

2) 인지 행동 치료의 시행시 초반에는 약물 요법을 병행하 는 것도 무난하리라 생각되며 이 때 약물은 의존성이 있는 벤조다이아핀계 혹은 비벤조다이핀계 수면제보다는 수면 유 도 효과가 있는 항우울제의 처방이 선호된다. 궁극적으로 약 물없이 $50 \%$ 내외의 환자가 인지 행동 치료로 도움을 받는 것으로 생각된다. 인지 행동 치료시 가장 중요한 것은 앞에 서 언급한 내용들을 교과서를 읽듯이 환자에게 이야기해서는 안 된다는 것이다. 이러한 치료 지침을 잘 지키게 되면 환자 의 불면증이 반드시 치료될 수 있다는 확신을 치료자가 가지 고 이러한 확신을 환자에게 심어주는 것이 중요하다. 